\title{
Anti-Epileptic Potential of Ziziphus Vulgaris and Ferula Asafoetida Extracts in Drug Induced Seizure Models of Experimental Mice
}

\author{
Nadia Anwar', Mahtab Ahmad Khan', Mehwish Bukhari', Hammad Ahmed ${ }^{1,3}$, Awais Ali Zaidi', Haroon \\ Arshad $^{4, *}$ \\ ${ }^{1}$ Faculty of Pharmacy, University of Lahore-54000, Pakistan \\ ${ }^{2}$ Faculty of Pharmacy, University of Central Punjab, Lahore-54000, Pakistan \\ ${ }^{3}$ Department of Pharmacology, Sialkot Medical College, Sialkot-51040, Pakistan. \\ ${ }^{4}$ Health Department, Government of the Punjab, Lahore-54000, Pakistan
}

\begin{abstract}
Authors' Contributions
1,3 performed the experiments and compiled the data.

2 designed the Study.

4 analyzed the data.

4,6 Manuscript was written

5 Coordinated the project.

2, 6 Final version of the manuscript was prepared
\end{abstract}

\section{Article info.}

Received: November 02, 2019

Accepted: July 14, 2020

Funding Source: Nil

Conflict of Interest: Nil

Cite this article: Anwar N, Khan MA, Bukhari

M, Ahmed H, Zaidi AA, Arshad H. Anti-

Epileptic Potential of Ziziphus Vulgaris and

Ferula Asafoetida Extracts in Drug Induced

Seizure Models of Experimental Mice. RADS J

Pharm Pharm Sci. 2020; 8(1):37-46.

*Address of Correspondence Author:

dr.haroonarshad@gmail.com

\section{ABSTRACT}

Background: Ziziphus vulgaris (ZV) and Ferula asafoetida (FA) have phenolic compounds with potential anti-epileptic activity.

Objective: This study was aimed to investigate the anti-epileptic potential of hydroalcoholic (30:70) crude extracts of ZV and FA.

Methods: Different doses $(5 \mathrm{mg} / \mathrm{ml}, 15 \mathrm{mg} / \mathrm{ml}, 25 \mathrm{mg} / \mathrm{ml})$ of extracts from ZV and FA were separately administered intraperitoneally to groups (7/group) of male albino mice $(20-30 \mathrm{~g})$. Phenytoin $(15 \mathrm{mg} / \mathrm{ml}$, intraperitoneal) was used as positive control. After $30 \mathrm{~min}$, tonic-clonic seizures were induced by intraperitoneal administration of picrotoxin $(6 \mathrm{mg} / \mathrm{ml})$ and strychnine $(4 \mathrm{mg} / \mathrm{ml})$ in separate groups. Animals were monitored for $1 \mathrm{~h}$ and different parameters including onset and frequency of seizures and protection (against mortality \& seizures) were determined.

Results: A dose dependent significant delay in onset and decrease in seizure frequency as well as mortality was observed in animals treated with plant extracts (ZV and FA). Positive control (phenytoin) also showed significant delay in seizure onset and decreased the seizure frequency.

Conclusion: The plant extracts (ZV and FA) contain the phenolic compounds which may induce the GABAergic transmission that could be the most probable mechanism for their anti-epileptic activity. Molecular studies and histopathological analysis are required to elucidate the exact anti-epileptic mechanisms of ZV and FA extracts.

Keywords: Ziziphus vulgaris, Ferula asafetida, Anti-epileptic plants, Strychnine-induced seizures, Picrotoxin-induced seizures.

\section{INTRODUCTION}

Epilepsy is a neuronal disorder showing the sign of seizures which can be experienced spontaneously or in routine whereas, a single episode of seizure is not considered as epilepsy and known as non-epileptic seizures [1]. The global prevalence of active epilepsy is $0.5-1.0 \%$ which may be even more in elderly $(>60$ years) population [2]. Epileptic seizures can be classified as partial, generalized, absence, tonicclonic, tonic, clonic, myoclonic, atonic, mixed seizures, and status epilepticus [3]. Tonic seizures involve sudden stiffening and contraction of the muscles while clonic seizures involve rhythmic twitching or jerking of muscles. Tonic-clonic seizures are a combination of these two types in a specific pattern [4]. The cause of seizure may differs with the type of epilepsy, whether the epileptic foci 
are localized or extensively spread to the other parts of the brain but mostly epilepsy is idiosyncratic [5]. Possible causes of seizure include stress, druginduced, abnormal dietary patterns (excessive alcohol intake), menstrual cycle and certain infections [6]. The type and intensity of the seizures can be identified using diagnostic techniques such as Electro Encephalo Graph (EEG), Brain Scan, past medical history and different blood tests [7].

Medications can manage seizures in majority of epileptic patients however; $30 \%$ of the epileptic patients do not respond to medications and therefore, require surgical interventions [8]. Surgical interventions attain the curative treatment of epilepsy in which the patient can either become seizure free or he requires palliative care to decrease the seizure frequency [9]. The approved medication possesses unwanted effects including cognitive [10] and neuropsychological effects [11]. The imminent resistance to conventional drugs urges the need of alternative treatment options including herbal medications. Ziziphus vulgaris is a medicinal plant that belongs to family Rhamnaceae and possess anxiolytic [12], antibacterial, antifungal [13], analgesic [14] and anti-hyperlipidemic activities with potential to treat different ailments like diabetes mellitus [15] and neurological disorders [16]. Ziziphus jujube (ZV) is a medicinal plant that belongs to family Rhamnaceae. The use of ingredients from $\mathrm{ZV}$ in the treatment of the epileptic seizures has already been reported [17]. Phytochemical analysis of Ziziphus vulgaris and Ziziphus jujube reveals the presence of same pharmacological active compounds. Their fruits are rich in the phenolic compounds such as catechin, epicatechin, rutin, p-hydroxy-benzoic acid, chlorogenic acid, caffeic acid, ferulic acids, vitamins and minerals [18].

Ferula asafetida (FA) is another medicinal plant belonging to family Umbelliferae and has been used in traditional medicines because of its antihypertensive [19], antifungal, anti-diabetic [20], antiinflammatory [21], anti-mutagenic [22] and antiviral activities [23]. FA comprises of $68 \%$ of carbohydrates, $16 \%$ of moisture, $4 \%$ protein, $1 \%$ of fat, $7 \%$ of minerals, $4 \%$ of fiber, resin ( 40 to $65 \%$ ), gum (20 to $25 \%$ ) and volatile oil (4 to 20\%) [24]. Both the medicinal plants including FA and ZV are enriched with flavonoids which are believed to be responsible for their anti-convulsant potential [25]. In addition to flavonoids, FA also contains other important ingredients like esters of ferulic acid, assafoetidnol, umbelliferon, luteolin and volatile oils [26, 27]

The toxicity studies revealed that extracts from both the plants ( $Z V$ \& FA) were safe in animal testing. The treatment of rats with alcoholic extract of ZV (100 $\mathrm{mg} / \mathrm{kg}$ ) for 3 months produced no functional or structural disturbances in vital organs and the oral LD50 in mice was $3820 \mathrm{mg} / \mathrm{kg}$ [28]. Moreover, rats did not show any signs of acute toxicity with oral administration of $F A$ at doses up to $5000 \mathrm{mg} / \mathrm{kg}$ [29]. It was hypothesized that these both plants (ZV \& FA) had certain constituents i.e. catechin, gallalocatechin, kaempferol, quercetin and rutin with potential to treat epileptic seizures. [25]. Picrotoxin is considered as $\mathrm{GABA}_{A}$ receptor antagonist that acts by modifying the function of chloride ion channel [30]. Strychnine is the potential competitive antagonist of glycine and blocks the inhibitory effects of the glycine at all glycine receptors [31]. Drug-induced (i.e. strychnine and picrotoxin-induced) epilepsy mouse models exert the local foci in the brain by disturbing the normal excitatory and inhibitory neurotransmitter levels and are widely used to evaluate the anti-seizure effects of different drugs [32]. Strychnine and picrotoxininduced epilepsy models interrupt the activity of neurotransmitters such as GABA and glutamate that are involved in the pathogenesis of seizures [33]. We aimed to study the anti-seizure activities of each of the ZV and FA hydroalcoholic crude extracts in mouse models of picrotoxin and strychnine-induced tonic-clonic seizures and to elucidate their proposed mechanisms of action [34].

\section{MATERIALS AND METHODS}

\section{Chemicals and equipment}

Standard equipment and analytical grade chemicals were used. Chemicals including diazepam, sodium valproate, strychnine and picrotoxin were purchased from Sigma-Aldrich, USA. Equipment includes digital weighing balance (Shimadzu, AY62 Japan), incubator (Memmert, Beschickung-Loading Modell 100-800), refrigerator (Dawlance, Pakistan), rotary evaporator (Dihan LabTech Co. LTD) and vortex mixer (Dihan LabTech co. Ltd. LVM-202). Ziziphus vulgaris and Ferula asafetida were procured from local market. Specimen samples of ZV and FA dried plants were identified by Dr. Zaheer-ud-Din, Associate Professor Department of Botany, Government College University, Lahore, Pakistan under voucher numbers 
Gc.Herb.Bot.3475 and Gc.Herb.Bot.2963 respectively.

\section{Preparation of extracts}

Whole dried plants were crushed into coarse powder in an electric blender and separately soaked in hydroalcoholic mixture $(30: 70)$ at room temperature with occasional shaking. Soaked material of each plant was then filtered through muslin cloth and Whatman filter paper (grade 1). In order to get maximum yield the process of soaking and filtration was repeated two more times. The filtrate was evaporated to a dark brown mass (at $40{ }^{\circ} \mathrm{C}$ under vacuum) in a rotary evaporator followed by drying at room temperature and the resultant extract was refrigerated at $-4{ }^{\circ} \mathrm{C}$ until used [35].

\section{Experimental animals}

Male and female Swiss albino mice weighing between 30 - $35 \mathrm{~g}$ were obtained from the animal house of University of Lahore, Pakistan. Free access of ad libitum was given to mice. Animals were kept on fasting one night before experiment but were allowed a free access to water. Guidelines of Institutional Research Ethics Committee, The University of Lahore, Lahore, Pakistan (approval number: IREC17-107) were followed during the experiments. A total of 140 mice were divided into 20 groups (7 mice / group) by the random selection of mice in each group.

\section{Administration of extracts to animals}

The extracts (ZV \& FA), picrotoxin and strychnine were diluted in distilled water while phenytoin solution was used in an un-diluted form. Picrotoxin $(1 \mathrm{mg})$ and strychnine $(1 \mathrm{mg}$ ) were separately diluted in $10 \mathrm{ml}$ of distilled water and administered intraperitoneally (6 $\mathrm{mg} / \mathrm{kg}$ and $4 \mathrm{mg} / \mathrm{kg}$ respectively). Stock solutions of both extracts (ZV \& FA) were prepared by diluting 100 $\mathrm{mg}$ of each extract in $100 \mathrm{ml}$ of distilled water and the diluted extracts were separately injected intraperitoneally in different doses $(5 \mathrm{mg} / \mathrm{kg}, 15$ $\mathrm{mg} / \mathrm{kg}$, and $25 \mathrm{mg} / \mathrm{kg}$ ).

\section{Picrotoxin-induced seizures}

Anticonvulsant effects of plant extracts (ZV \& FA) were studied in-vivo by using picrotoxin-induced seizure model. Both plants extracts (ZV \& FA) were separately injected to the animals groups. Hydroalcoholic crude extracts (ZV \& FA) were injected intraperitoneally at different doses $(5 \mathrm{mg} / \mathrm{kg}$, $15 \mathrm{mg} / \mathrm{kg}$, and $25 \mathrm{mg} / \mathrm{kg}$ ) which were selected on the basis of available literature and found to be pharmacologically active in mice to all groups except negative and positive controls [34]. Positive control group received phenytoin $(15 \mathrm{mg} / \mathrm{kg}$ ). After $30 \mathrm{~min}$, picrotoxin (6 $\mathrm{mg} / \mathrm{kg})$ was administered intraperitoneally in individual groups to induce seizure. Each animal was placed in individual plastic cage for observation for at least $60 \mathrm{~min}$ after toxin injection. Onset time of seizures, seizures frequency and protection against mortality and seizures were noted [36]. The number of seizures during the observation time was observed and the frequency was calculated by taking mean of observations in each group [37]. Time interval between induction of disease and demonstration of seizure was measured. The delay in onset of seizure was calculated in comparison with the control group. Protection was expressed as percent inhibition relative to vehicle control.

\section{Strychnine-induced seizures}

Anticonvulsant effects of plant extracts ( $Z V$ \& FA) were also studied in-vivo by using strychnine-induced seizure model. Both plants extract ( $Z V$ \& FA) and phenytoin was separately injected to the animals groups in same doses as described for picrotoxininduced seizures. After $30 \mathrm{~min}$, strychnine $(4 \mathrm{mg} / \mathrm{kg}$ ) was administered intraperitoneally to induce epilepsy by post synaptic inhibition of glycine. Each animal was placed in individual plastic cage for observation for at least $60 \mathrm{~min}$ after toxin injection. Onset time of seizures, seizures frequency, protection against mortality and seizures were noted in same manner as described for picrotoxin-induced seizures [36].

\section{Statistical Analysis}

As the data was normally distributed variably by a bell shape histogram so, the sum results were presented as means \pm SEM (standard errors of means). Parametric data were assessed by the method of analysis of one way ANOVA (analysis of variance) followed by Tukey's test. Graphics and statistical hypothesis testing were done using Graph Pad Prism (version 5.0) and IBM SPSS version 19.

\section{RESULTS}

\section{Picrotoxin-induced seizures}

The intraperitoneal administration of ZA and FA extracts showed a dose dependent protection from tonic-clonic seizures in picrotoxin-induced seizures in mouse model. 

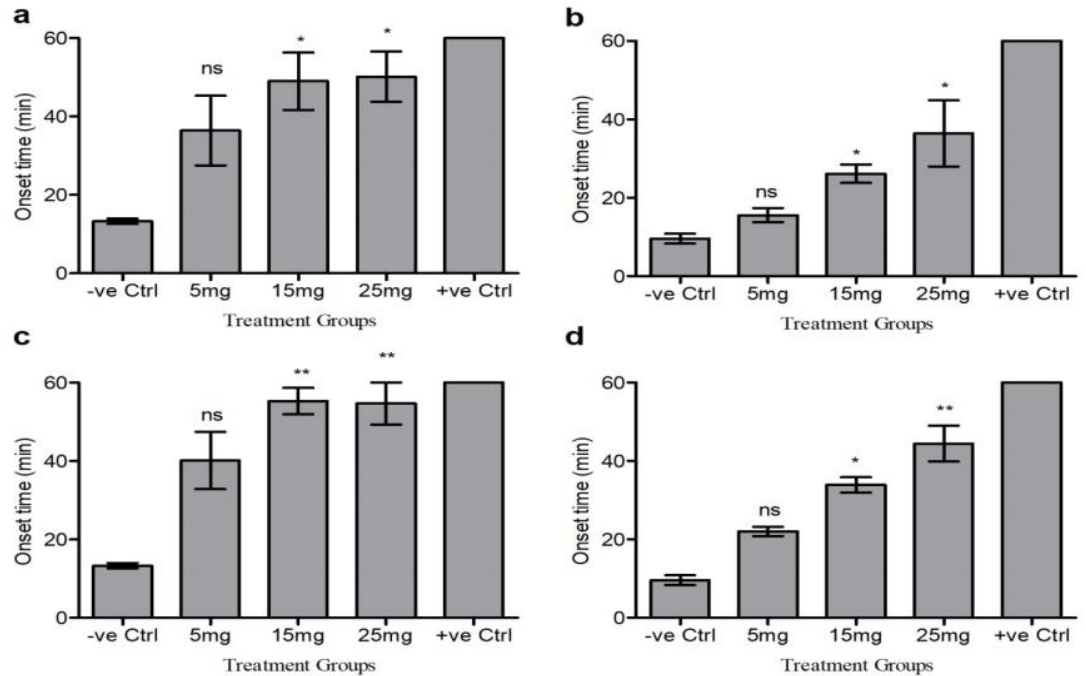

Figure 1. Graph showing the onset of seizures induced in different treatment groups: (a); Effects of ZV extract in picrotoxin-induced seizures, (b); Effects of ZV extract in strychnine-induced seizures, (c); Effects of FA extract in picrotoxin-induced seizures and (d); Effects of FA extract in strychnine-induced seizures. Values are expressed as mean \pm SEM, where $\mathrm{n}=7,{ }^{* *}=P<0.01$ (very significant); ${ }^{*}=P<0.05$ (significant) and $\mathrm{ns}=$ non-significant compared to negative control using one way ANOVA followed by Tukey's test.

Table 1. The effects of FA and ZV extracts on onset time, frequency and percentage protection against seizure \& mortality in picrotoxin and strychnine-induced seizures.

\begin{tabular}{|c|c|c|c|c|c|c|c|c|c|}
\hline \multirow{2}{*}{\multicolumn{2}{|c|}{\begin{tabular}{|c|} 
Effects \\
Treatments
\end{tabular}}} & \multicolumn{2}{|c|}{ Onset of seizure (min) } & \multicolumn{2}{|c|}{ Frequency of seizure } & \multicolumn{4}{|c|}{$\%$ protection } \\
\hline & & \multirow{2}{*}{$\begin{array}{l}\text { Picrotoxin- } \\
\text { induced }\end{array}$} & \multirow{2}{*}{$\begin{array}{l}\text { Strychnine- } \\
\text { induced }\end{array}$} & \multirow{2}{*}{$\begin{array}{l}\text { Picrotoxin- } \\
\text { induced }\end{array}$} & \multirow{2}{*}{$\begin{array}{l}\text { Strychnine- } \\
\text { induced }\end{array}$} & \multicolumn{2}{|c|}{$\begin{array}{l}\text { Picrotoxin-induced } \\
\text { seizure }\end{array}$} & \multicolumn{2}{|c|}{$\begin{array}{c}\text { Strychnine-induced } \\
\text { seizure }\end{array}$} \\
\hline & & & & & & Seizures & Mortality & Seizures & Mortality \\
\hline \multirow{5}{*}{$\begin{array}{l}\text { Effects } \\
\text { of ZV } \\
\text { extract }\end{array}$} & $\begin{array}{c}\text {-ve } \\
\text { control }\end{array}$ & 13.28 & 9.57 & 2 & 2 & 0 & 0 & 0 & 0 \\
\hline & $\begin{array}{c}5 \\
\mathrm{mg} / \mathrm{kg}\end{array}$ & $36.43 \mathrm{~ns}$ & $15.57 \mathrm{~ns}$ & $1.14 \mathrm{~ns}$ & $1.14 \mathrm{~ns}$ & $35 \mathrm{~ns}$ & 70 * & $15 \mathrm{~ns}$ & 70 * \\
\hline & $\begin{array}{c}15 \\
\mathrm{mg} / \mathrm{kg}\end{array}$ & 49 * & 26.14 * & $0.57^{* *}$ & 1 * & $65^{* *}$ & 80 * & 20 * & 70 ** \\
\hline & $\begin{array}{c}25 \\
\mathrm{mg} / \mathrm{kg}\end{array}$ & 50.14 * & 36.42 * & $0.28 * * *$ & 0.71 ** & $75^{* *}$ & $100 * * *$ & 40 * & 70 ** \\
\hline & $\begin{array}{c}\text { +ve } \\
\text { control }\end{array}$ & 60 & 60 & 0 & 0 & 100 & 100 & 100 & 100 \\
\hline \multirow{5}{*}{$\begin{array}{l}\text { Effects } \\
\text { of FA } \\
\text { extract }\end{array}$} & $\begin{array}{c}-\mathrm{ve} \\
\text { control }\end{array}$ & 13.28 & 9.57 & 2 & 2 & 0 & 0 & 0 & 0 \\
\hline & $\begin{array}{c}5 \\
\mathrm{mg} / \mathrm{kg}\end{array}$ & 40.14 ns & 22 ns & $1 \mathrm{~ns}$ & $1.42 \mathrm{~ns}$ & $40 \mathrm{~ns}$ & $70 \mathrm{~ns}$ & $6 \mathrm{~ns}$ & $40 \mathrm{~ns}$ \\
\hline & $\begin{array}{c}15 \\
\mathrm{mg} / \mathrm{kg}\end{array}$ & 55.28 ** & $33.85^{*}$ & $0.71 *$ & 1 * & 60 ** & $100^{* * *}$ & 20 * & 70 * \\
\hline & $\begin{array}{c}25 \\
\mathrm{mg} / \mathrm{kg}\end{array}$ & $54.66^{* *}$ & 44.42 ** & $0.57^{* *}$ & $0.85^{* *}$ & $70 * * *$ & $100^{* * *}$ & 40 * & 70 ** \\
\hline & $\begin{array}{l}\text { +ve } \\
\text { control }\end{array}$ & 60 & 60 & 0 & 0 & 100 & 100 & 100 & 100 \\
\hline
\end{tabular}

Values are expressed as mean \pm SEM, where $\mathrm{n}=7,{ }^{* \star *}=P<0.001$ (highly significant results); ${ }^{* *}=P<0.01$ (very significant); ${ }^{*}=P<0.05$ (significant); ns $=$ non-significant compared to negative control. 


\section{Onset of seizures}

The administration of picrotoxin $(6 \mathrm{mg} / \mathrm{kg}$, intraperitoneally) frequently (less than $20 \mathrm{~min}$ ) induced seizures as seen in untreated (negative) control group (Table 1). The effects of FA and ZV extracts on onset time of picrotoxin-induced seizures are summarized in Table 1. The treatment of mice with hydroalcoholic crude extract of ZV at doses (15, $25 \mathrm{mg} / \mathrm{kg}$, intraperitoneal) significantly $(P<0.05)$ delayed the onset of seizures as shown in Figure 1a. Moreover, the treatment of animals with FA hydroalcoholic extract showed very significant $(P<$ $0.01)$ delay in onset of seizure at doses $(15,25$ $\mathrm{mg} / \mathrm{kg}$, intraperitoneal) (Figure 1c). The positive control (phenytoin, $15 \mathrm{mg} / \mathrm{kg}$, intraperitoneal) completely inhibited the onset of seizure throughout the observation period (60 $\mathrm{min}$ ) (Table 1).

\section{Frequency of seizures}

The administration of picrotoxin $(6 \mathrm{mg} / \mathrm{kg}$, intraperitoneally) showed high frequency (calculated as mean of total animals) of seizures as seen in untreated (negative) control group (Table 1). The effects of FA and ZV extracts on frequency of picrotoxin-induced seizures are summarized in Table 1. The treatment of mice with hydroalcoholic crude extract of ZV at doses (25 mg/kg, intraperitoneal) showed highly significant $(P<0.001)$ reduction in seizure frequency (Figure 2a). In addition, the treatment of animals with FA hydroalcoholic extract $(15,25 \mathrm{mg} / \mathrm{kg})$ significantly $(P<0.05$ and $P<0.01$ respectively) reduced the frequency of seizures as depicted in Figure 2c. The positive control (phenytoin, $15 \mathrm{mg} / \mathrm{kg}$, intraperitoneal) completely inhibited the induction of seizure throughout the observation period (60 min) (Figure 2).

\section{Protection against mortality and seizures}

The treatment of animals with hydroalcoholic crude extracts of ZV and FA not only protected the animals against picrotoxin-induced seizures but also reduced the mortality rate in a dose dependent manner as summarized in Table 1. The untreated (negative) control group did not show any protection against seizures and mortality. Both (ZV \& FA) extracts were more effective in protecting the animals against mortality (100\% protection) as compared to protection against seizures (75\% \& 70\% protection respectively) at doses $(25 \mathrm{mg} / \mathrm{kg}$, intraperitoneal) as depicted in Figure 3a \& c. However, positive control (phenytoin, $15 \mathrm{mg} / \mathrm{kg}$, intraperitoneal) showed $100 \%$ protection against both mortality and seizures (Figure $3 \mathbf{a} \& \mathbf{c}$ ). a
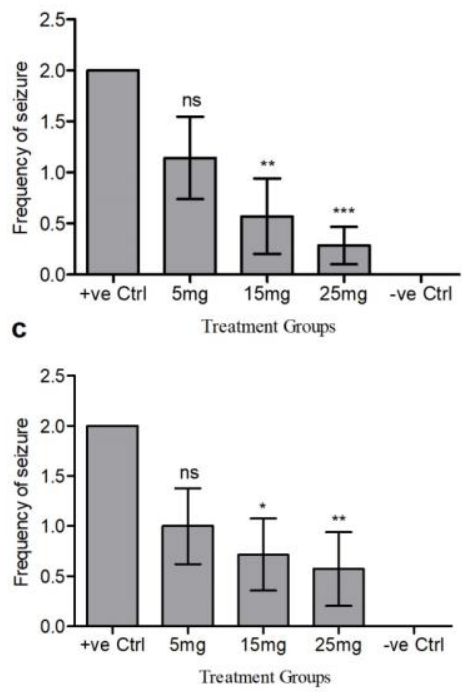

b

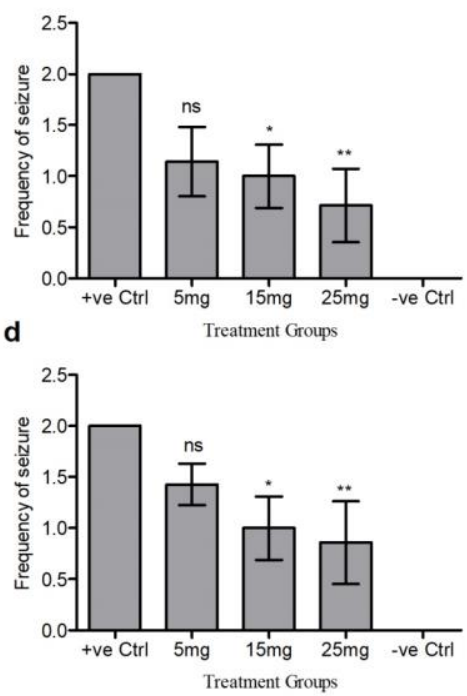

Figure 2. Graph showing the frequency of seizures induced in different treatment groups: (a); Effects of ZV extract in picrotoxin-induced seizures, (b); Effects of ZV extract in strychnine-induced seizures, (c); Effects of FA extract in picrotoxin-induced seizures and (d); Effects of FA extract in strychnine-induced seizures. Values are expressed as mean \pm SEM, where $\mathrm{n}=7,{ }^{* *}=P<0.001$ (highly significant); ${ }^{* *}=P<0.01$ (very significant); ${ }^{*}=$ $P<0.05$ (significant) and $n s=$ non-significant compared to negative control using one way ANOVA followed by Tukey's test. 


\section{Strychnine-induced seizures}

The intraperitoneal administration of $Z A$ and FA extracts showed a dose dependent protection from seizures in strychnine-induced seizures in mouse model however less effective than in picrotoxininduced seizures.

\section{Onset of seizures}

The administration of strychnine $(4 \mathrm{mg} / \mathrm{kg}$, intraperitoneal) frequently (in less than $20 \mathrm{~min}$ ) induced seizures as seen in untreated (negative) control group (Table 1). The effects of FA and ZV extracts on onset time of strychnine-induced seizures are summarized in Table 1. The treatment of animals with ZV hydroalcoholic extract significantly $(P<0.05)$ delayed the onset of seizure at doses $(15,25 \mathrm{mg} / \mathrm{kg}$, intraperitoneal) (Figure 1b). Moreover, treatment of animals with $\mathrm{FA}$ at doses $(15,25 \mathrm{mg} / \mathrm{kg}$, intraperitoneal) hydroalcoholic crude extract showed significant and very significant $(P<0.05, P<0.01$ respectively) delay in onset of seizures (Figure 1d). In addition, positive control (phenytoin, $15 \mathrm{mg} / \mathrm{kg}$, intraperitoneal) completely inhibited the onset of seizure throughout the observation period $(60 \mathrm{~min})$ (Figure 1).
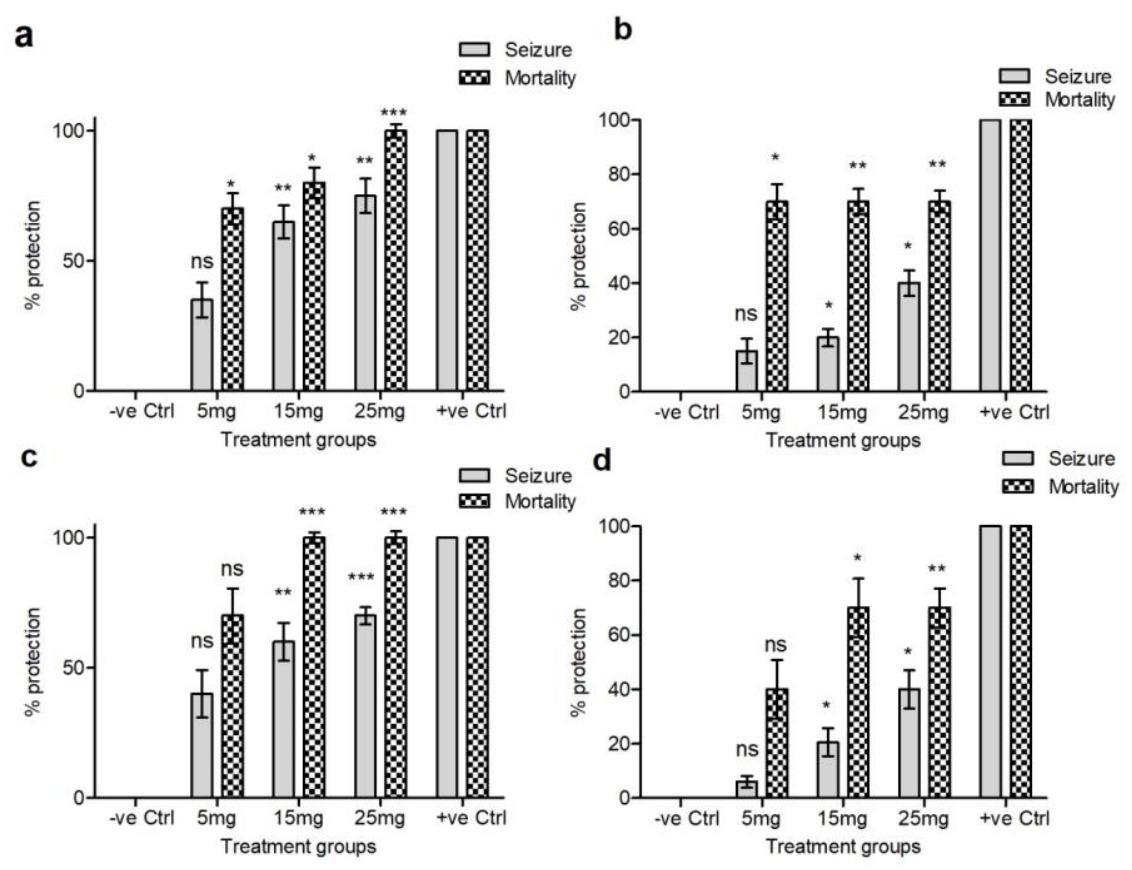

Figure 3. Graph showing the percentage protection against seizures and mortality in different treatment groups: (a); Effects of ZV extract in picrotoxin-induced seizures, (b); Effects of ZV extract in strychnine-induced seizures, (c); Effects of FA extract in picrotoxin-induced seizures and (d); Effects of FA extract in strychnine-induced seizures. Values are expressed as mean \pm SEM, where $\mathrm{n}=7,{ }^{* * *}=P<0.001$ (highly significant); ${ }^{* *}=P<0.01$ (very significant); ${ }^{*}=P<0.05$ (significant) and $\mathrm{ns}=$ non-significant compared to negative control using one way ANOVA followed by Tukey's test.

\section{Frequency of seizures}

The administration of strychnine $(4 \mathrm{mg} / \mathrm{kg}$, intraperitoneally) showed high frequency (calculated by taking mean of total animals) of seizures as seen in untreated (negative) control group (Figure 2). The effects of FA and ZV extracts on frequency of strychnine-induced seizures are summarized in Table 1. The treatment of mice with either extract of $Z V$ and
FA at doses $(15,25 \mathrm{mg} / \mathrm{kg}$, intraperitoneal) showed very significant and significant $(P<0.01$ and $P<0.05$ respectively) reduction in seizure frequency (Figure 2b \& d). In addition, positive control (phenytoin, 15 $\mathrm{mg} / \mathrm{kg}$, intraperitoneal) completely inhibited the induction of seizures throughout the observation period (60 min) (Figure 2). 


\section{Protection against mortality and seizures}

The treatment of animals with hydroalcoholic crude extracts of ZV and FA not only protected the animals against strychnine-induced seizures but also reduced the mortality rate in a dose dependent manner as summarized in Table 1. The untreated (negative) control group did not show any protection against seizures and mortality. Both (ZV \& FA) extracts were more effective in protecting the animals against mortality (70\% protection) as compared to protection $(40 \%)$ against seizures at doses $(25 \mathrm{mg} / \mathrm{kg}$, intraperitoneal) as depicted in Figure $\mathbf{3 b} \& \mathbf{d}$. However, positive control (phenytoin, $15 \mathrm{mg} / \mathrm{kg}$, intraperitoneal) showed $100 \%$ protection against both mortality and seizures (Figure $\mathbf{3 b} \mathbf{\&} \mathbf{d}$ ).

\section{DISCUSSION}

The data obtained in this study for the first time demonstrated that hydroalcoholic crude extracts from Ziziphus vulgaris (ZV) and Ferula asafoetida (FA) showed highly significant anticonvulsant activity in experimental model of tonic-clonic seizures in mice. Epilepsy is a neuronal disorder showing the sign of seizures which can be experienced spontaneously or in routine [1]. To the best of knowledge, epilepsy remains a major global medical challenge and still not completely curable [38]. ZV and FA have certain constituents like phenolic compounds with potential to treat epileptic seizures. These extracts had been used in folklore for the treatment of different neuromuscular disorders since many years. We aimed to study the anti-seizure activities of each of the hydroalcoholic crude extracts from ZV and FA in mouse models of picrotoxin and strychnine-induced tonic-clonic seizures.

The hydroalcoholic crude extract of ZV and FA were injected intraperitoneally and exhibited anti-epileptic effects against picrotoxin and strychnine-induced seizures in a dose dependent manner as observed at doses 5,15 and $25 \mathrm{mg} / \mathrm{kg}$ respectively in different groups of Swiss albino mice $(n=7)$. Picrotoxin most likely produces seizures by inhibiting the gamma amino butyric acid (GABA) neurotransmission [39]. GABA is the major inhibitory neurotransmitter in the brain, the major cause of seizure is considered as inhibition of GABAergic neurotransmission [40]. Seizures can be treated by improving the GABAergic neurotransmission. However, strychnine produces seizures by acting as selective, competitive antagonist to block the inhibitory effect of glycine at all glycine receptors [41]. Both extracts significantly delayed the onset time (Figure 1) and lowered the frequency of seizures at high doses (Figure 2). It is pertinent to mention that the FA hydroalcoholic extract provided the maximum protection against picrotoxin-induced seizures even at low dose of 15 $\mathrm{mg} / \mathrm{kg}$ that might reflects its high efficacy and potency if applied in clinical settings as depicted in Figure 1c. In addition, ZV \& FA extracts showed more protection against seizures and mortality in picrotoxin-induced seizure model as compared to strychnine-induced seizure model at high doses (Figure 3 ).

This study suggested that ZV and FA hydroalcoholic extracts are effective against picrotoxin and strychnine-induced seizures. Phenolic compounds have the potential to modulate the GABA receptors. In some studies certain flavonoids like ferulic acid, rutin and $p$-hydroxy-benzoic acid have shown the GABA like effects on benzodiazepine binding site and modulated the inhibitory effects of GABA [42]. Such ligand binding sites are classified as positive allosteric modulators, antagonists, or negative allosteric modulators according to their spectrum of intrinsic efficacy towards the GABA receptor [43]. As the phenolic compounds are among the important phytochemicals contained in both plant extracts (ZV and FA) therefore, the most likely mechanism for the anti-epileptic activity of hydroalcoholic plant extracts ( $\mathrm{ZV}$ and FA) could be the GABAergic transmission. The GABAergic potential can be determined by sleep test which is indicative of sleep induction and sleep potentiating outcomes [44, 45]. Future studies could be designed to determine the GABAergic potential of these extracts for better mechanistic insights. Moreover, molecular and histopathological studies are also required to elucidate the anti-epileptic mechanisms and to isolate the phenolic compounds and other phytochemicals responsible for their antiseizure activities.

\section{CONCLUSION}

It can be concluded from above discussion that hydroalcoholic crude extracts from Ziziphus vulgaris and Ferula asafetida showed highly significant dose dependent anticonvulsant activity in experimental model of tonic-clonic seizures in mice. Our study is a step forward towards new horizons in the alternate treatment options for epilepsy. Molecular studies and 
histopathological analysis was not performed due to lack of resources. More in-vivo studies are required to validate the findings in a larger size cohort and to elucidate the anti-epileptic mechanisms and safety profiles of ZV and FA hydroalcoholic crude extracts.

\section{CONCLUSION}

In a nutshell, anti-inflammatory and analgesic potential of Aitchisonia rosea could plausibly be owing to alkaloids, flavonoids, phenols, tannins along with anti-oxidant effect of flavonoids. Nevertheless, activity directed fractionation of ARME to separate active constituents from plant and further studies to explicate probable mode of action are mandatory to rationalize its use.

\section{REFERENCES}

1. Banerjee PN, Filippi D, Hauser WA. The descriptive epidemiology of epilepsy-a review. Epilepsy Res. 2009; 85(1):31-45. doi: 10.1016/j.eplepsyres.2009.03.003.

2. Sander JW. The epidemiology of epilepsy revisited. Curr Opin Neurol. 2003; 16(2):165-70. doi: 10.1097/01.wco.0000063766.15877.8e.

3. Karceski S, Morrell MJ, Carpenter D. Treatment of epilepsy in adults: expert opinion, 2005. Epilepsy Behav. 2005;7:1-64. doi: 10.1016/j.yebeh.2005.06.001.

4. Fisher RS, Boas WVE, Blume W, Elger C, Genton $\mathrm{P}$, Lee $\mathrm{P}$, et al. Epileptic seizures and epilepsy: definitions proposed by the International League Against Epilepsy (ILAE) and the International Bureau for Epilepsy (IBE). Epilepsia. 2005; 46(4):470-2 . doi: 10.1111/j.00139580.2005.66104.x.

5. Kato K, Suzuki M, Kanno H, Sekino S, Kusakabe $\mathrm{K}$, Okada $\mathrm{T}$, et al. Distinct role of growth hormone on epilepsy progression in a model of temporal lobe epilepsy. J Neurochem. 2009; 110(2):509-19. doi: 10.1111/j.1471-4159.2009.06132.x.

6. Aldarmaa J, Liu Z, Long J, Mo X, Ma J, Liu J. Anticonvulsant effect and mechanism of Astragalus mongholicus extract in vitro and in vivo: protection against oxidative damage and mitochondrial dysfunction. Neurochem Res. 2010; 35(1):33. doi: 10.1007/s11064-009-0027-4.

7. Wolf P. Of cabbages and kings: some considerations on classifications, diagnostic schemes, semiology, and concepts. Epilepsia. 2003; 44(1):1-3. doi: 10.1046/j.1528-1157. 2003.09202_2.x.
8. De Boer HM, Mula M, Sander JW. The global burden and stigma of epilepsy. Epilepsy Behav. 2008; 12(4):540-6. doi: 10.1016/j.yebeh.2007.12.019.

9. Bowen JM, Snead OC, Chandra K, Blackhouse G, Goeree R. Epilepsy care in Ontario: an economic analysis of increasing access to epilepsy surgery. Ontario H Tech Assess Ser. 2012; 12(18):1. https://www.ncbi.nlm.nih.gov/sars-cov-2/.

10. Ortinski $P$, Meador KJ. Cognitive side effects of antiepileptic drugs. Epilepsy Behav. 2004; 5:60-5. doi: 10.1016/j.yebeh.2003.11.008.

11. Kwan P, Brodie MJ. Neuropsychological effects of epilepsy and antiepileptic drugs. The Lancet. 2001; 357(9251):216-22. doi: 10.1016/S01406736(00)03600-X.

12. Lin $\mathrm{Y}-\mathrm{C}$, Hsieh M-T, Chen C-F, Cheng H-Y, Peng $\mathrm{W}-\mathrm{H}$. Anxiolytic effect of ting-chih-wan in mouse behavior models of anxiety. The Am J Chinese med. 2003; 31(01):47-59. doi: 10.1142/S0192415X03000709.

13. Pirbalouti AG, Broujeni VN, Momeni M, Poor FM, Hamedi B. Antibacterial activity of Iranian medicinal plants against Streptococcus iniae isolated from rainbow trout (Oncorhynchus mykiss). Arch Biol Sci. 2011; 63(1):59-66. doi: 10.2298/ABS1101059P

14. Adzu B, Amos S, Wambebe C, Gamaniel K. Antinociceptive activity of Zizyphus spina-christi root bark extract. Fitoterapia. 2001; 72(4):344-50. doi: 10.1016/s0367-326x(00)00289-6.

15. Solati J, Soleimani N. Antihyperglycemic and antihyperlipidemic effects of Ziziphus vulgaris $\mathrm{L}$. onreptozocin-induced diabetic adult male Wistar rats. Acta Diabetol. 2010; 47(1):219-23. doi: org/10.1007/s00592-009-0166-8

16. Saki K, Bahmani $M$, Rafieian-Kopaei $M$, Hassanzadazar H, Dehghan K, Bahmani F, et al. The most common native medicinal plants used for psychiatric and neurological disorders in Urmia city, northwest of Iran. Asian Pac J Trop Dis. 2014; 4:S895-S901. doi: 10.1016/S2222-1808(14)607544

17. Pahuja M, Mehla J, Reeta K, Joshi S, Gupta YK. Hydroalcoholic extract of Zizyphus jujuba ameliorates seizures, oxidative stress, and cognitive impairment in experimental models of epilepsy in rats. Epilepsy Behav. 2011;21(4):35663. doi: 10.1016/j.yebeh.2011.05.013.

18. Li J-w, Ding S-d, Ding X-I. Comparison of antioxidant capacities of extracts from five cultivars of Chinese jujube. Pro Biochem. 2005; 40(11):3607-13. doi: 10.9755/ejfa.v25i3.10828. 
19. Fatehi M, Farifteh $F$, Fatehi-Hassanabad $Z$. Antispasmodic and hypotensive effects of Ferula asafoetida gum extract. J Ethnopharmacol. 2004; 91(2-3):321-4. doi: 10.1016/j.jep.2004.01.002.

20. Abu-Zaiton AS. Anti-diabetic activity of Ferula assafoetida extract in normal and alloxan-induced diabetic rats. Pak J Biol Sci. 2010; 13(2):97.doi: 10.3923/pjbs.2010.97.100.

21. Rollinger JM, Steindl TM, Schuster D, Kirchmair J, Anrain K, Ellmerer EP, et al. Structure-based virtual screening for the discovery of natural inhibitors for human rhinovirus coat protein. J Med Chem. 2008; 51(4):842-51. doi.org/10.1021/jm701494b.

22. Abraham SK, Kesavan P. Genotoxicity of garlic, turmeric and asafoetida in mice. Mut Research. 1984; 136(1):85-8. doi: 10.1016/01651218(84)90138-1.

23. Gowda N, Malathi V, Suganthi R. Effect of some chemical and herbal compounds on growth of Aspergillus parasiticus and aflatoxin production. Ani Feed Sci Tech. 2004; 116(3-4):281-91. doi: 10.1016/j.anifeedsci.2004.02.008

24. Shinnar S, Berg AT. Does antiepileptic drug therapy prevent the development of "chronic" epilepsy? Epilepsia. 1996; 37(8):701-8. doi: 10.1111/j.1528-1157.1996.tb00639.x.

25. Diniz TC, Silva JC, Lima-Saraiva SRGd, Ribeiro FPRdA, Pacheco AGM, de Freitas RM, et al. The role of flavonoids on oxidative stress in epilepsy. Oxid Med Cell Longev. 2015. doi: 10.1155/2015/171756.

26. Smith M, Wilcox KS, White HS. Discovery of antiepileptic drugs. Neurotherapeutics. 2007; 4(1):12-7. doi: 10.3390/ph3072090

27. Bienvenu T, Poirier K, Friocourt G, Bahi N, Beaumont D, Fauchereau $F$, et al. ARX, a novel Prd-class-homeobox gene highly expressed in the telencephalon, is mutated in X-linked mental retardation. Hum Mol Genet. 2002; 11(8):981-91. doi: $10.1093 / \mathrm{hmg} / 11.8 .981$

28. Abdel-Zaher AO, Salim SY, Assaf MH, Abdel-Hady $\mathrm{RH}$. Antidiabetic activity and toxicity of Zizyphus spina-christi leaves. J Ethnopharmacol. 2005; 101(1):129-38. doi: 10.1016/j.jep.2005.04.007.

29. Goudah A, Abdo-El-Sooud K, Yousef MA. Acute and subchronic toxicity assessment model of Ferula assa-foetida gum in rodents. Vet World. 2015; 8(5):584. doi: 10.14202/vetworld.2015.584589

30. Vogel HG, Vogel WH. Drug discovery and evaluation: pharmacological assays: Springer Sci \& Busi Med. 2013; 345-57. https://www.springer.com/gp/book/9783540709954
31. Alachkar A, Łażewska D, Latacz G, Frank A, Siwek A, Lubelska A, et al. Studies on Anticonvulsant Effects of Novel Histamine H3R Antagonists in Electrically and Chemically Induced Seizures in Rats. Intl j mol sci. 2018; 19(11):3386. doi: 10.3390/ijms19113386.

32. Anissian D, Ghasemi-Kasman M, Khalili-Fomeshi $\mathrm{M}$, Akbari A, Hashemian M, Kazemi S, et al. Piperine-loaded chitosan-STPP nanoparticles reduce neuronal loss and astrocytes activation in chemical kindling model of epilepsy. Int $\mathrm{J}$ Biol Macromol. 2018; 107:973-83. doi: 10.1016/j.ijbiomac.2017.09.073.

33. Löscher W. Critical review of current animal models of seizures and epilepsy used in the discovery and development of new antiepileptic drugs. Seizure. 2011; 20(5):359-68. doi: 10.1016/j.seizure.2011.01.003.

34. Elger CE, Schmidt D. Modern management of epilepsy: a practical approach. Epilepsy Behav. 2008; 12(4):501-39. doi: 10.1016/j.yebeh.2008.01.003.

35. Wangchuk P, Tobgay T. Contributions of medicinal plants to the Gross National Happiness and Biodiscovery in Bhutan. J ethnobio ethnomed. 2015; 11(1):48. doi: 10.1186/s13002-015-0035-1.

36. Tiwari D, Brager DH, Rymer JK, Bunk AT, White AR, Elsayed NA, et al. MicroRNA inhibition upregulates hippocampal A-type potassium current and reduces seizure frequency in a mouse model of epilepsy. Neurobiol Dis. 2019; 130:104508.

37. Agarwal P, Singh A, Gaurav K, Goel S, Khanna H, Goel R. Evaluation of wound healing activity of extracts of plantain banana (Musa sapientum var. paradisiaca) in rats. Indian J Exp Biol. 2009. doi: 10.1016/j.nbd.2019.104508.

38. Peng A, Qiu X, Lai W, Li W, Zhang L, Zhu X, et al. Altered composition of the gut microbiome in patients with drug-resistant epilepsy. Epilepsy Res. 2018; 147:102-7. doi: 10.1016/j.eplepsyres.2018.09.013.

39. Randrianarivo E, Maggi F, Nicoletti M, Rasoanaivo $P$. Evaluation of the anticonvulsant activity of the essential oil of Myrothamnus moschatus in convulsion induced by pentylenetetrazole and picrotoxin. Asian Pac J Trop Biomed. 2016; 6(6):501-5. doi: org/10.1016/j.apjtb.2016.01.017

40. Zhi H, Wu C, Yang Z. SCN1A rs3812718 polymorphism is associated with epilepsy: An updated meta-analysis. Epilepsy Res. 2018; 142:81-7. doi: 10.5114/aoms.2016.59737

41. de Souza JL, Faiola AS, Miziara CSMG, de Manreza MLG. The Perceived Social Stigma of People with Epilepsy with regard to the Question 
of Employability. Neurol Res Int. 2018; 112:14-7 doi: $10.1155 / 2018 / 4140508$.

42. Shrestha S, Park J-H, Lee D-Y, Cho J-G, Cho S, Yang $\mathrm{H}-\mathrm{J}$, et al. Rhus parviflora and its biflavonoid constituent, rhusflavone, induce sleep through the positive allosteric modulation of GABAAbenzodiazepine receptors. J Ethnopharmacol. 2012; 142(1):213-20. doi: 10.1016/j.jep.2012.04.047.

43. Griebel G, Perrault G, Tan S, Schoemaker H, Sanger DJ. Pharmacological studies on synthetic flavonoids: comparison with diazepam.
Neuropharmacology. 1999; 38(7):965-77. doi: 10.1016/s0028-3908(99)00026-x.

44. Camfield P, Camfield C. Regression in children with epilepsy. Neurosci Biobehav Rev. 2018. doi: 10.1016/j.neubiorev.2018.12.008

45. Sivakumar P, De Giorgio F, Ule AM, Neeves J, Nair RR, Bentham $M$, et al. TDP-43 mutations increase HNRNP A1-7B through gain of splicing function. Brain. 2018; 141(12):e83-e. doi: 10.1093/brain/awy260.

\footnotetext{
This is an Open Access article distributed under the terms of the Creative Commons Attribution License (http://creativecommons.org/licenses/by/4.0), which permits unrestricted use, distribution, and reproduction in any medium, provided the original work is properly cited.
} 